\title{
Pemberian diet ekstra formula komersial dan diet ekstra filtrat ikan gabus intradialisis serta pengaruhnya terhadap kadar serum albumin dan kreatinin pasien dengan hemodialisis di RSU Dr. Saiful Anwar Malang
}

\author{
Etik Sulistyowati ${ }^{1}$, Hamam Hadi², Susetyowati ${ }^{3}$, Atma Gunawan $^{4}$
}

\begin{abstract}
Background: Nowadays chronic kidney disease (CKD) is a serious health problem because of its increasing incidence. In Indonesia, approximately there are 100 CKD patients per 1 million people per year. Hemodialysis is one of ways to prolong CKD patient's life that should be done recurrently and for a long time. However, hemodialysis causes loss of nutrients leading to high prevalence of malnutrition among CKD patients. Until today intradialysis diet therapy which can replace loss of nutrients particularly protein has not been initiated as part of diet therapy in Indonesian hospitals. To improve nutritional status and minimize mortality rate, oral intradialysis diet therapy with proper formula is needed.

Objective: To study the effect of the supply of commercial formula and local catfish filtrate extra diet to albumin and creatinine serum level among hemodialysis patients.

Method: The study was experimental with randomized control trial design carried out at Dialysis Installation of Dr. Saiful Anwar Hospital, Malang. There were as many as 36 hemodialysis patients divided into 3 groups; 1 group with standard diet, 1 group with commercial formula and standard diet, and 1 group with local catfish filtrate and standard diet. Data were obtained through interview, note taking, and laboratory tests which consisted of subject characteristics in weight, height, albumin and creatinin serum level as well as food intake one day before, during and one day after hemodialysis. Data analysis was done descriptively and inferentially using chi square, anova, and paired t-test. The conclusion was based on significance level $(\alpha) 0.05$ or $p<0.05$.

Results: There was no significant difference in the characteristics of the subject at the beginning of the study with average albumin serum level $3.61 \pm 0.48 \mathrm{~g} / \mathrm{dL}$ and creatinine serum level $9.04 \pm 2.73 \mathrm{mg} / \mathrm{dL}$. There was no difference in average energy and protein intake of the subject. At the end of the study average albumin serum level was $3.38 \pm 0.42 \mathrm{~g} / \mathrm{dL}$, creatinine serum level $8.34 \pm 3.6 \mathrm{mg} / \mathrm{dL}$, and there was significant difference in albumin serum level $(p=0.000)$ of the subject. Although there was an increase of creatinine serum level in the group with local catfish filtrate extra diet, it was statistically insignificant.

Conclusion: There was significant effect of the supply of commercial formula and local catfish filtrate extra diet to increase of albumin serum level of the subject and there was no significant effect of the supply of extra diet to creatinine serum level; however, the supply of local catfish filtrate extra diet could maintain creatinine serum level.
\end{abstract}

KEY WORDS hemodialysis, intradialysis diet therapy, commercial formula, local catfish filtrate, albumin serum, creatinine serum

\section{PENDAHULUAN}

Penyakit ginjal kronis saat ini merupakan masalah kesehatan yang penting mengingat insidennya yang meningkat. Di Indonesia, diperkirakan jumlahnya 100 penderita per satu juta penduduk dalam setahun (1). Tindakan hemodialisis merupakan salah satu cara untuk mempertahankan kelangsungan hidup penderita penyakit ginjal kronis tahap akhir (2). Data menunjukkan bahwa penderita penyakit ginjal kronis dengan hemodialisis yang ditanggung PT Askes pada tahun 1995 berjumlah 2.131 kasus, tahun 2000 berjumlah 2.617 kasus, dan tahun 2004 meningkat lagi menjadi 6.319 kasus (3).

Prevalensi pasien hemodialisis rutin dengan malnutrisi pada penelitian-penelitian terdahulu cukup tinggi, yaitu berkisar antara $23-76 \%$ (4). Kadar serum albumin yang rendah menandakan adanya hubungan dengan tingginya risiko kematian pada pasien dengan hemodialisis (5). Rendahnya kadar albumin pada pasien dengan hemodialisis disebabkan rerata asupan protein harian lebih rendah daripada yang dianjurkan, sementara di sisi lain terjadi kehilangan protein ke dalam dialisat pada setiap kali dialisis (6).

Pemberian nutrisi intradialisis terbukti dapat meningkatkan kadar albumin pasien. Foulks (7) melaporkan adanya perbedaan signifikan pada perubahan berat badan,

Politeknik Kesehatan Departemen Kesehatan R.I. Malang, Jl. Besar ljen No. 77 C, Malang, e-mail: poltekkes_malang@yahoo.com

2 Magister Gizi Kesehatan UGM, JI Farmako, Sekip Utara, Yogyakarta 55281, e-mail: hamam@indosat.net.id

3 Instalasi Gizi RSUP Dr. Sardjito, Jl. Kesehatan, Yogyakarta, e-mail: susetyowati2000@yahoo.com

4 RSU Dr. Saiful Anwar, Jl. Jaksa Agung Suprapto No. 2, Malang 
serum albumin, dan total protein pada pasien yang mendapatkan nutrisi parenteral intradialisis dengan yang tidak. Hasil penelitian Ruggian et al. (8) juga menunjukkan peningkatan serum albumin yang signifikan pada 31 pasien hemodialisis yang mendapatkan intradialytic parenteral nutrition (IDPN).

Pada umumnya, terapi diet intradialisis di Indonesia belum diberikan sebagai bagian terapi diet pasien dengan hemodialisis, baik nutrisi parenteral maupun enteral dan oral, bahkan pasien dengan hemodialisis tidak diberikan diet khusus intradialisis. Anjuran dari ahli gizi agar penderita mengkonsumsi makanan maupun formula komersial khusus intradialisis sampai saat ini belum diamati pengaruhnya terhadap status gizi. Formula komersial khusus untuk pasien dengan hemodialisis memiliki komposisi zat gizi yang telah disesuaikan dengan kebutuhan pasien, sehingga memberikan kemudahan dalam penyusunan diet.

Hasil penelitian FitzGerald et al. (9) menunjukkan bahwa pemberian protein susu pada pasien dengan hemodialisis dapat membantu menurunkan tekanan darah, namun faktor ekonomi seringkali menjadi kendala dalam penggunaannya. Salah satu alternatif yang dapat dilakukan untuk mengganti protein yang hilang selama hemodialisis dan merupakan pengembangan di bidang pangan dan gizi adalah pemberian filtrat ikan gabus pada diet penderita intradialisis.

Soemarko (10) melaporkan bahwa dari beberapa studi kasus didapatkan hasil adanya peningkatan kadar albumin yang relatif lebih tinggi pada penderita yang mendapatkan menu ekstra filtrat ikan gabus dibandingkan penderita yang mendapat menu putih telur. Filtrat ikan gabus menurut Santosa (11) mengandung protein sebesar $7,6 \mathrm{~g} / \mathrm{dL}$ dan albumin sebesar 5,6 g/dL serta kandungan asam amino esensial yang cukup lengkap. Hasil penelitian Suprayitno et al. (12) juga menunjukkan bahwa penggunaan filtrat ikan gabus pada pasien pascaoperasi di samping dapat mempercepat penyembuhan luka dibandingkan pemberian human serum albumin, harganya juga relatif jauh lebih murah dan dapat dibuat dengan teknologi sederhana di rumah sakit. Namun demikian, filtrat ikan gabus belum pernah diberikan sebagai salah satu bentuk terapi diet intradialisis pada pasien hemodialisis yang sangat dibutuhkan untuk mengganti protein yang hilang pada saat dialisis dan mencegah katabolisme protein, sehingga dapat mempertahankan kadar serum kreatinin dalam batas normal, mengatasi hipoalbuminemia, dan meningkatkan imunitas.

Rumah Sakit Umum Dr. Saiful Anwar Malang merupakan salah satu rumah sakit rujukan bagi pasien dengan hemodialisis di Jawa Timur. Berdasarkan data bulan Juni 2006, pasien yang tercatat melakukan hemodialisis rutin berjumlah lebih dari 250 pasien per bulan. Sampai saat ini belum pernah dilakukan penelitian untuk mengetahui pengaruh pemberian diet ekstra formula komersial secara intradialisis terhadap kadar serum albumin dan kreatinin pasien dengan hemodialisis. Demikian juga dengan filtrat ikan gabus yang telah terbukti secara klinis dari beberapa hasil penelitian dapat meningkatkan kadar serum albumin pada pasien luka bakar dan dapat mempercepat penyembuhan luka $(11,12)$, namun belum pernah dilakukan untuk pasien dengan hemodialisis yang seringkali mengalami malnutrisi dengan kadar serum albumin yang cenderung rendah.

Penelitian ini bertujuan untuk mengetahui pengaruh pemberian diet ekstra komersial dan diet ekstra filtrat ikan gabus intradialisis terhadap peningkatan kadar serum albumin dan optimalisasi kadar serum kreatinin pasien hemodialisis di RSU Dr. Saiful Anwar Malang.

\section{BAHAN DAN METODE}

Penelitian ini merupakan penelitian eksperimental dengan rancangan randomized control trial, yang dilakukan terhadap pasien hemodialisis di Instalasi Dialisis RSU Dr. Saiful Anwar Malang mulai bulan April sampai dengan Juli 2007.

Kriteria inklusi adalah pasien hemodialisis rutin 2 kali/ minggu dalam satu bulan terakhir, dewasa berusia 20-60 tahun, pasien dengan dialyzer baru pada awal penelitian dan selanjutnya reused (pakai ulang), dialisat bikarbonat dan hemodialisis berlangsung 3,5-4 jam, secara klinis tidak mengalami udema dan ascites, dan mendapatkan diet oral. Kriteria eksklusi meliputi: dirawat di rumah sakit selama penelitian, didiagnosis nefropati diabetik, sirosis hepatis dan $\mathrm{HBSAg}^{+}$, alergi terhadap ikan dan susu, penderita pernah absen hemodialisis selama penelitian (kurang dari 6 kali hemodialisis dalam 3 minggu). Besar sampel minimal dihitung berdasarkan rumus uji hipotesis untuk dua rata-rata populasi dan diperoleh sebanyak 9 orang untuk masing-masing kelompok (13). Subjek penelitian dipilih secara random sampling dengan bantuan tabel bilangan random (14). Jenis-jenis intervensi dirandomisasi pada tingkat individu dengan metode alokasi rasio $1: 1: 1$. Ketiga intervensi tersebut adalah diet standar tanpa diet ekstra, diet standar + ekstra formula komersial, dan diet standar + ekstra filtrat ikan gabus yang diberikan intradialisis kepada subjek selama 6 kali hemodialisis rutin (3 minggu).

Diet standar merupakan makanan yang diberikan intradialisis pada pasien dengan hemodialisis berupa makanan selingan (snack) sesuai dengan menu rumah sakit, sedangkan diet standar tanpa diet ekstra merupakan makanan standar yang diberikan intradialisis pada pasien dengan hemodialisis berupa larutan glukosa $10 \%$ sebanyak $100 \mathrm{~mL}$ selama 6 kal hemodialisis rutin (3 minggu). Diet ekstra formula komersial merupakan makanan yang diberikan intradialisis pada pasien dengan hemodialisis berupa $110 \mathrm{~mL}$ produk komersial dan diet ekstra filtrat ikan gabus berupa $100 \mathrm{~mL}$ filtrat ikan gabus, masing-masing dilakukan selama 6 kali hemodialisis rutin (3 minggu).

Data yang dikumpulkan meliputi: data karakteristik subjek, berat badan, tinggi badan, asupan energi dan pro- 
tein, kadar serum albumin, dan kreatinin. Pengumpulan data dilakukan melalui wawancara dengan bantuan kuesioner, pencatatan, pengukuran, dan pemeriksaan laboratorium. Penyuntingan, pengkodean, dan tabulasi dilakukan terhadap data yang telah dikumpulkan. Pengolahan data dilakukan dengan program dan analisis data dilakukan secara deskriptif dan uji statistik chi square, anova, dan paired t-test. Kesimpulan adanya perbedaan atau pengaruh yang signifikan secara statistik menggunakan tingkat kemaknaan ( ) 0,05 atau $p<0,05$.

\section{HASIL}

Penelitian ini melibatkan 36 pasien hemodialisis di Instalasi Dialisis RSU Dr. Saiful Anwar Malang yang dibagi menjadi 3 kelompok secara acak, yaitu: kelompok subjek yang mendapat diet standar tanpa diet ekstra, kelompok subjek yang mendapat diet standar + ekstra formula komersial, dan kelompok subjek yang mendapat diet standar + ekstra filtrat ikan gabus. Intervensi dilakukan selama 6 kali hemodialisis rutin ( 3 minggu) pada masing-masing subjek.

\section{Karakteristik subjek}

Subjek penelitian terdiri dari 17 pasien $(47,2 \%)$ perempuan

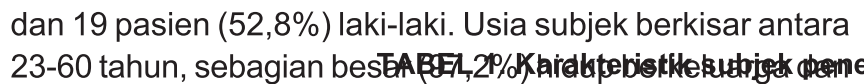

$100 \%$ subjek hidup bersama dengan keluarga. Sebagian besar subjek berpendidikan akhir sekolah menengah atas dengan status pekerjaan sebagian besar tidak bekerja $(33,3 \%)$. Subjek telah menjalani hemodialisis rutin 2 kali/ minggu selama 7-48 bulan dengan biaya dari PTAskes selama kurang lebih 3,5-4 jam setiap kali hemodialisis. Dialisat yang digunakan adalah natrium bikarbonat dengan dialyzer jenis High Flux FB 130 PGA.

Keluhan yang sering dialami subjek adalah pusing setelah hemodialisis, sedangkan gangguan gastrointestinal yang sering dialami adalah mual dan penurunan nafsu makan (anoreksia). Obat-obatan yang dianjurkan oleh dokter untuk mengatasi keluhan tersebut antara lain: obat antihipertensi, antiemetik, obat gatal, obat batuk, dan multivitamin. Rerata pengambilan cairan (penurunan berat badan) pra- dan pascahemodialisis sebesar 2,1 kg. Adapun karakteristik subjek penelitian berdasarkan faktor demografi dan keluhan disajikan pada Tabel 1.

Hasil uji statistik chi square menunjukkan tidak terdapat perbedaan yang signifikan pada jenis kelamin, pekerjaan, pendidikan, dan keluhan gastrointestinal (mual dan muntah) pada ketiga kelompok ( $p>0,05$ ). Demikian pula hasil uji statistik anova terhadap rerata usia, lama hemodialisis, dan selisih berat badan pra- dan pascahemodialisis menunjukkan hasil yang tidak berbeda signifikan ( $p>0,05)$, sehingga dapat dikatakan bahwa subjek pada ketiga kelompok bersifat

\begin{tabular}{|c|c|c|c|c|}
\hline \multirow[b]{2}{*}{ Karakteristik } & \multicolumn{3}{|c|}{ Kelompok } & \multirow[b]{2}{*}{$\mathbf{p}$} \\
\hline & $\begin{array}{c}\text { Diet standar } \\
\text { tanpa diet ekstra } \\
(n=12)\end{array}$ & $\begin{array}{c}\text { Diet standar + } \\
\text { FK } \\
(n=12)\end{array}$ & $\begin{array}{c}\text { Diet standar + } \\
\text { FIG } \\
(n=12)\end{array}$ & \\
\hline Usia (tahun) & $49,67 \pm 11,74$ & $47,17 \pm 6,39$ & $50,17 \pm 4,99$ & $0,637^{\text {a) }}$ \\
\hline \multicolumn{5}{|l|}{ Jenis kelamin } \\
\hline Laki-laki & $6(50,0 \%)$ & $5(41,7 \%)$ & $6(50,0 \%)$ & \multirow[t]{2}{*}{$0,739^{b)}$} \\
\hline Perempuan & $6(50,0 \%)$ & $7(58,3 \%)$ & $6(50,0 \%)$ & \\
\hline \multicolumn{5}{|l|}{ Pekerjaan } \\
\hline PNS/ABRI & $3(25,0 \%)$ & $4(33,3 \%)$ & $3(25,0 \%)$ & \multirow[t]{4}{*}{$0,409^{b)}$} \\
\hline Swasta & $3(25,0 \%)$ & $3(25,0 \%)$ & $3(25,0 \%)$ & \\
\hline Tidak bekerja & $5(41,7 \%)$ & $3(25,0 \%)$ & $4(33,3 \%)$ & \\
\hline Wiraswasta & $1(8,3 \%)$ & $2(16,7 \%)$ & $2(16,7 \%)$ & \\
\hline \multicolumn{5}{|l|}{ Pendidikan } \\
\hline$\leq$ SLTP & $4(33,3 \%)$ & $3(25,0 \%)$ & $4(33,3 \%)$ & \multirow[t]{2}{*}{$0,096^{\mathrm{b})}$} \\
\hline$\geq$ SLTA & $8(66,7 \%)$ & $9(75,0 \%)$ & $8(66,7 \%)$ & \\
\hline Lama hemodialisis (bulan) & $18,5 \pm 12$ & $19,5 \pm 12,68$ & $18,4 \pm 9,87$ & $0,968^{\text {a) }}$ \\
\hline Delta BB pra-pasca HD (kg) & $2,08 \pm 1,63$ & $2,13 \pm 0,6$ & $2,04 \pm 1,15$ & $0,985^{\mathrm{a})}$ \\
\hline \multicolumn{5}{|l|}{$\begin{array}{l}\text { Mual } \\
\text { Mella prasca in (ny) }\end{array}$} \\
\hline $\mathrm{Ya}$ & $5(41,7 \%)$ & $6(50,0 \%)$ & $6(50,0 \%)$ & \multirow[t]{2}{*}{$0,739^{b)}$} \\
\hline Tidak & $7(58,3 \%)$ & $6(50,0 \%)$ & $6(50,0 \%)$ & \\
\hline \multicolumn{5}{|l|}{ Anoreksia } \\
\hline Ya & $5(41,7 \%)$ & $8(66,7 \%)$ & $6(50,0 \%)$ & \multirow[t]{2}{*}{$1^{b)}$} \\
\hline Tidak & $7(58,3 \%)$ & $4(33,3 \%)$ & $6(50,0 \%)$ & \\
\hline
\end{tabular}

\section{Keterangan:}

a) uji anova

b) uji chi square

FK (formula komersial)

FIG (filtrat ikan gabus)

BB (berat badan)

HD (hemodialisis) 
Indeks massa tubuh subjek berkisar antara 15,62-28,91 $\mathrm{kg} / \mathrm{m}^{2}$ dengan rerata $21,09 \mathrm{~kg} / \mathrm{m}^{2}$. Rerata kadar serum albumin awal sebesar 3,61 $\pm 0,48 \mathrm{~g} / \mathrm{dL}$, sedangkan hasil pemeriksaan kadar serum kreatinin awal subjek menunjukkan rerata sebesar $9,04 \pm 2,73 \mathrm{mg} / \mathrm{dL}$. Meskipun terdapat perbedaan rerata indeks massa tubuh, kadar serum albumin, dan kadar serum kreatinin dari ketiga kelompok, secara statistik perbedaan ini tidak signifikan $(p>0,05)$, sehingga dapat dikatakan bahwa pada awal penelitian subjek bersifat homogen (Tabel 2). sehari-hari tidak signifikan, baik berdasarkan persen kebutuhan maupun per kg BBI (berat badan ideal) per hari $(p=0,367 ; p=$ $0,763)$.

Diet intradialisis diberikan kepada subjek sekitar 60 menit setelah hemodialisis dimulai. Selama penelitian, subjek dari ketiga kelompok selalu mengkonsumsi habis diet intradialisis yang diberikan dan tidak ditemukan gejala-gejala klinis yang berhubungan dengan efek merugikan setelah pemberian diet sampai penelitian berakhir.

TABEL 2. Karakteristik subjek penelitian berdasarkan status gizi pada awal penelitian

\begin{tabular}{lcccc}
\hline & \multicolumn{3}{c}{ Mean \pm SD } & p \\
\cline { 2 - 4 } Parameter status gizi & $\begin{array}{c}\text { Diet standar tanpa } \\
\text { diet ekstra }\end{array}$ & $\begin{array}{c}\text { Diet standar + } \\
\text { FK }\end{array}$ & $\begin{array}{c}\text { Diet standar + } \\
\text { FIG }\end{array}$ & \\
\hline IMT (kg/m ${ }^{2}$ ) & $20,5 \pm 2,84$ & $20,9 \pm 2,46$ & $21,84 \pm 5,69$ & 0,702 \\
Serum albumin (g/dL) & $3,69 \pm 0,59$ & $3,66 \pm 0,36$ & $3,49 \pm 0,47$ & 0,540 \\
Serum kreatinin (mg/dL) & $9,34 \pm 2,93$ & $9,28 \pm 2,16$ & $8,49 \pm 3,17$ & 0,710 \\
\hline Keterangan: & & & \\
FK (formula komersial) & & & \\
FIG (formula ikan gabus) & & & \\
IMT (indeks massa tubuh) & & &
\end{tabular}

\section{Asupan energi dan protein}

Asupan energi dan protein meliputi asupan pada satu hari sebelum dan sesudah hemodialisis serta pada hari saat hemodialisis. Pada umumnya pola makan subjek adalah 2-3 kali makan utama dan 1- 2 kali makanan selingan. Sumber protein hewani dan nabati juga dikonsumsi masing-masing sekitar 1-2 porsi sehari. Berdasarkan hasil anamnesis, sebagian besar subjek merasakan tidak ada perbedaan nafsu makan pada saat hemodialisis, sehari sebelum, dan sehari sesudah hemodialisis. Adapun rerata asupan energi dan protein subjek dari diet sehari-hari menurut kelompok disajikan pada Tabel 3. Hasil uji statistik anova menunjukkan bahwa perbedaan rerata asupan energi dan protein subjek dari diet

\section{Pengaruh pemberian diet intradialisis terhadap kadar serum albumin}

Kadar serum albumin akhir subjek (setelah pemberian diet) mengalami perubahan menjadi 12 subjek $(33,33 \%)$ mempunyai kadar albumin acceptable, 22 subjek $(61,11 \%)$ tergolong low, dan 2 subjek (5,56\%) tergolong deficient. Demikian pula dengan rerata kadar serum albumin juga mengalami penurunan dari $3,62 \mathrm{~g} / \mathrm{dL}$ menjadi $3,38 \mathrm{~g} / \mathrm{dL}$. Pada akhir penelitian, kadar serum albumin kelompok dengan diet ekstra filtrat ikan gabus mempunyai rerata paling tinggi, sedangkan rerata kadar serum albumin kelompok tanpa diet ekstra menjadi paling rendah. Rerata penurunan kadar serum albumin tertinggi dialami oleh subjek pada kelompok tanpa diet ekstra.

TABEL 3. Rerata asupan energi dan protein subjek menurut kelompok berdasarkan persen kebutuhan dan berat badan

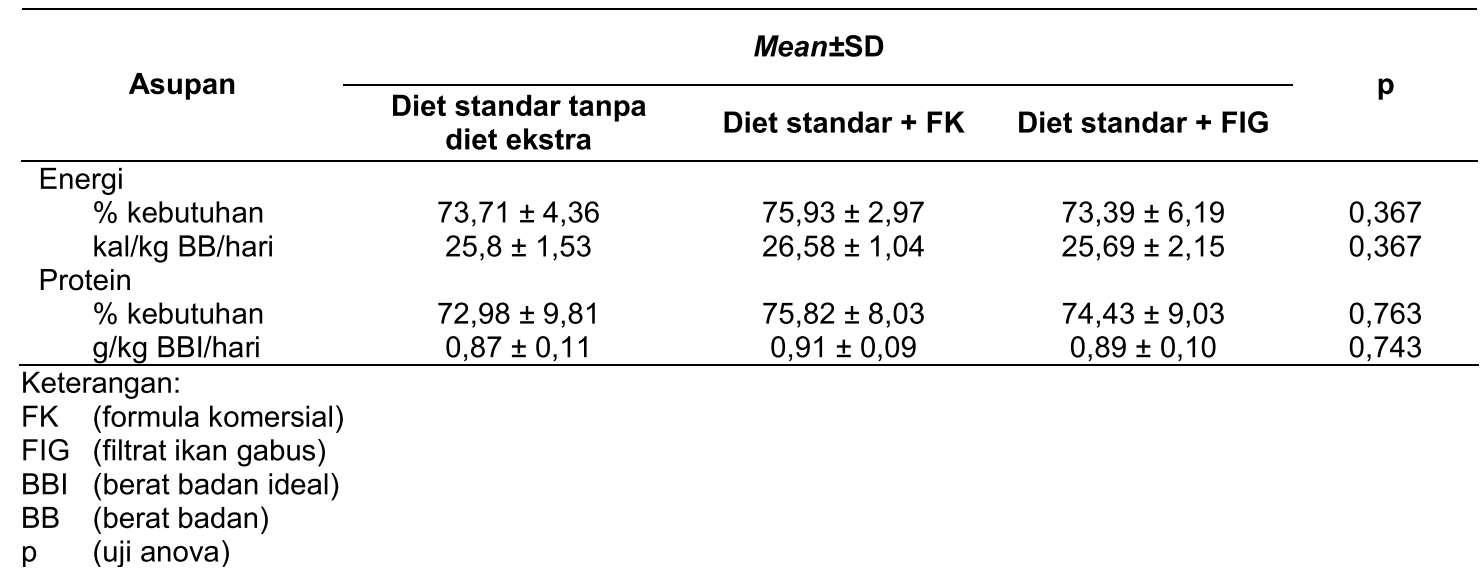


Gambar 1 menunjukkan bahwa kelompok tanpa diet ekstra mengalami penurunan kadar serum albumin dengan rerata sebesar $0,62 \pm 0,30 \mathrm{~g} / \mathrm{dL}$ dan hasil uji statistik ( $t$-test) menunjukkan adanya perbedaan yang signifikan antara kadar serum albumin sebelum dan sesudah pemberian diet pada kelompok ini $(p=0,001)$, demikian pula dengan status albumin subjek, hasil uji chi square menunjukkan adanya penurunan yang signifikan $(p=0,000)$.

Pada kelompok yang mendapatkan diet ekstra formula komersial juga mengalami penurunan sebesar 0,14 $\pm 0,21 \mathrm{~g} /$ dL. Hasil statistik perbedaan kadar serum albumin awal dan akhir pada kelompok ini juga signifikan ( $p=0,039)$, namun hasil uji chi square menunjukkan tidak ada penurunan yang signifikan status albumin subjek sebelum dan sesudah pemberian diet $(p>0,05)$ (Tabel 4).

Peningkatan kadar serum albumin terjadi pada kelompok yang mendapatkan diet ekstra filtrat ikan gabus dengan rerata $0,06 \pm 0,31 \mathrm{~g} / \mathrm{dL}$ dan terjadi peningkatan status albumin subjek yang signifikan $(p=0,021)$. Hasil uji chi square menunjukkan adanya perbedaan yang signifikan antara status albumin sebelum dan sesudah pemberian diet pada kelompok ini $(p<$ 0,05) (Tabel 5).
Perubahan kadar serum albumin sebelum dan sesudah penelitian serta selisih kadar serum albumin berdasarkan kelompok disajikan pada Tabel 6. Hasil uji statistik anova menunjukkan adanya perbedaan yang signifikan dari selisih kadar serum albumin sebelum dan sesudah pemberian diet ( $p=0,000)$. Uji lanjutan Duncan multiple range test (DMRT) menunjukkan bahwa selisih kadar serum albumin pada kelompok tanpa diet ekstra berbeda dengan kelompok yang mendapatkan diet ekstra, sedangkan kelompok yang mendapatkan diet ekstra selisih kadar serum albumin pada awal dan akhir penelitian tidak berbeda.

\section{Pengaruh pemberian diet intradialisis terhadap kadar serum kreatinin}

Pada akhir penelitian, rerata kadar serum kreatinin subjek mengalami penurunan dari 9,03 $\pm 2,73 \mathrm{mg} / \mathrm{dL}$ menjadi 8,34 \pm $3,62 \mathrm{mg} / \mathrm{dL}$ atau turun sebesar 0,69 $\pm 2,67 \mathrm{mg} / \mathrm{dL}$. Gambar 2 menunjukkan bahwa rerata penurunan kadar serum kreatinin tertinggi dialami oleh kelompok tanpa diet ekstra sebesar $1,54 \pm 3,21 \mathrm{mg} / \mathrm{dL}$, demikian pula untuk kelompok dengan diet ekstra formula komersial mengalami penurunan sebesar $0,63 \pm 2,99 \mathrm{mg} / \mathrm{dL}$. Namun demikian, kelompok dengan diet

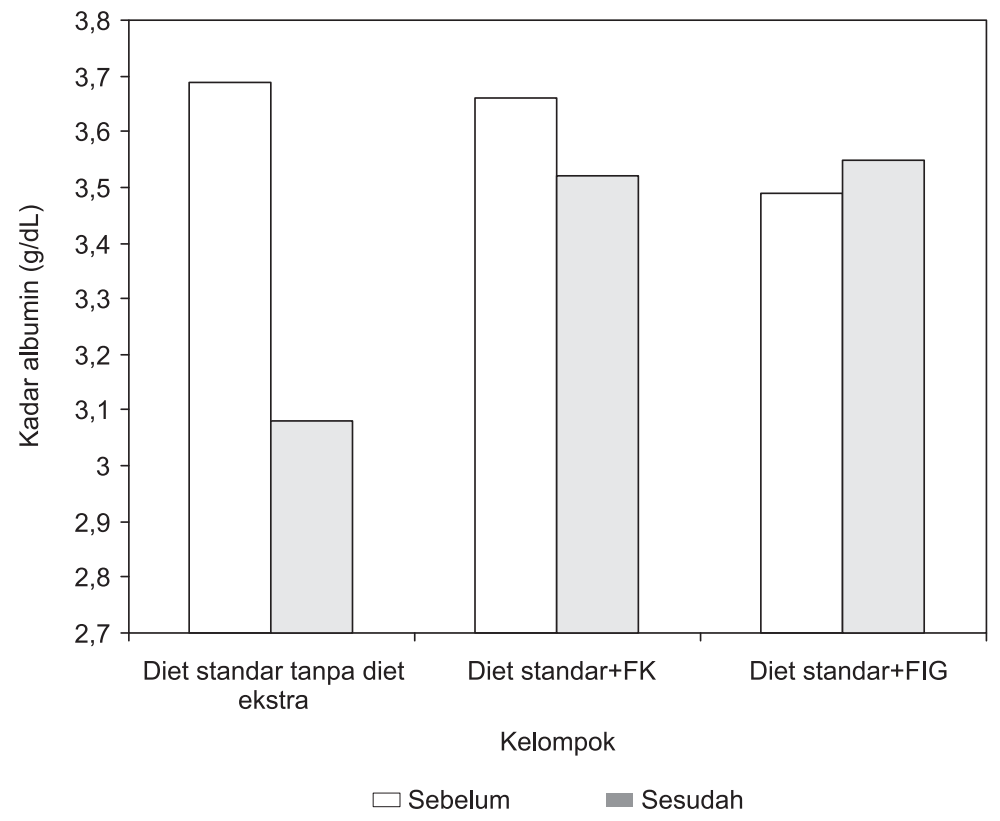

GAMBAR 1. Rerata kadar serum albumin subjek sebelum dan sesudah pemberian diet

TABEL 4. Distribusi subjek kelompok diet standar + FK berdasarkan status albumin sebelum dan sesudah pemberian diet

\begin{tabular}{ccccc}
\hline \multirow{2}{*}{ Waktu } & \multicolumn{3}{c}{ Status albumin } & \multirow{2}{*}{$\mathbf{p}$} \\
\cline { 2 - 4 } & Acceptable & Low & Deficient & 0,174 \\
\hline Sebelum pemberian diet & $6(50,0 \%)$ & $5(41,7 \%)$ & $1(8,3 \%)$ & \multirow{2}{*}{$0,1 \%)$} \\
Sesudah pemberian diet & $5(41,7 \%)$ & $6(50,0 \%)$ & $1(8,3 \%)$ & \\
\hline Keterangan: & & &
\end{tabular}

Keterangan:

FK (formula komersial)

p (uji chi square) 
TABEL 5. Distribusi subjek kelompok diet standar + FIG berdasarkan status albumin sebelum dan sesudah penelitian

\begin{tabular}{lcccc}
\hline \multirow{2}{*}{ Waktu } & \multicolumn{3}{c}{ Status albumin } & \multirow{2}{*}{$\mathbf{p}$} \\
\cline { 2 - 4 } & Acceptable & Low & Deficient & $0,021^{*}$ \\
\hline Sebelum & $5(41,7 \%)$ & $5(41,7 \%)$ & $2(16,6 \%)$ & \multirow{2}{*}{ Sesudah } \\
\hline
\end{tabular}

Keterangan:

FIG (filtrat ikan gabus)

* Signifikan ( $p<0,05$; uji chi square)

TABEL 6. Perubahan kadar serum albumin subjek sebelum dan sesudah pemberian diet

\begin{tabular}{|c|c|c|c|c|}
\hline \multirow[b]{2}{*}{ Kelompok } & \multicolumn{3}{|c|}{ Kadar serum albumin (g/dL) } & \multirow[b]{2}{*}{$\mathbf{p}$} \\
\hline & $\begin{array}{c}\text { Sebelum } \\
(\text { mean } \pm S D)\end{array}$ & $\begin{array}{c}\text { Sesudah } \\
(\text { mean } \pm S D)\end{array}$ & $\begin{array}{c}\text { Selisih } \\
(\text { mean } \pm S D)\end{array}$ & \\
\hline Diet standar tanpa diet ekstra & $3,69 \pm 0,59$ & $3,08 \pm 0,38$ & $-0,62 \pm 0,30^{a}$ & $0,000^{*}$ \\
\hline Diet standar + FK & $3,66 \pm 0,36$ & $3,52 \pm 0,35$ & $-0,14 \pm 0,21^{b)}$ & \\
\hline Diet standar + FIG & $3,49 \pm 0,47$ & $3,55 \pm 0,39$ & $0,06 \pm 0,31^{b)}$ & \\
\hline
\end{tabular}

Keterangan:

FK (formula komersial)

FIG (filtrat ikan gabus)

* Signifikan ( $p<0,05$; uji anova)

a), b) Uji Duncan multiple range test, notasi yang berbeda menunjukkan perbedaan notasi sama menunjukkan tidak ada perbedaan antar kelompok

ekstra filtrat ikan gabus justru mengalami peningkatan rerata kadar serum kreatinin sebesar 0,08 $\pm 1,39 \mathrm{mg} / \mathrm{dL}$. Dari hasil analisis statistik, perbedaan rerata kadar serum kreatinin ketiga kelompok pada akhir penelitian tidak signifikan ( $p=$ 0,827 ). Berdasarkan jumlah subjek, pada kelompok tanpa diet ekstra terjadi penurunan sebesar $50 \%$ dari yang tergolong mempunyai kadar serum kreatinin optimal menjadi kurang, sedangkan pada kelompok dengan diet ekstra formula komersial terjadi penurunan sebesar $8,3 \%$, dan pada kelompok dengan diet ekstra filtrat ikan gabus terjadi kenaikan sebesar $8,3 \%$ subjek yang tergolong mempunyai kadar se- rum kreatinin optimal. Hasil uji statistik t-test menunjukkan bahwa perubahan kadar serum kreatinin sebelum dan sesudah pemberian diet pada masing-masing kelompok juga tidak signifikan seperti tercantum pada Tabel 7.

\section{BAHASAN}

\section{Karakteristik subjek}

Hasil penelitian menunjukkan tidak terdapat perbedaan yang signifikan dalam hal karakteristik subjek secara demografi dan gangguan gastrointestinal seperti mual dan anoreksia,

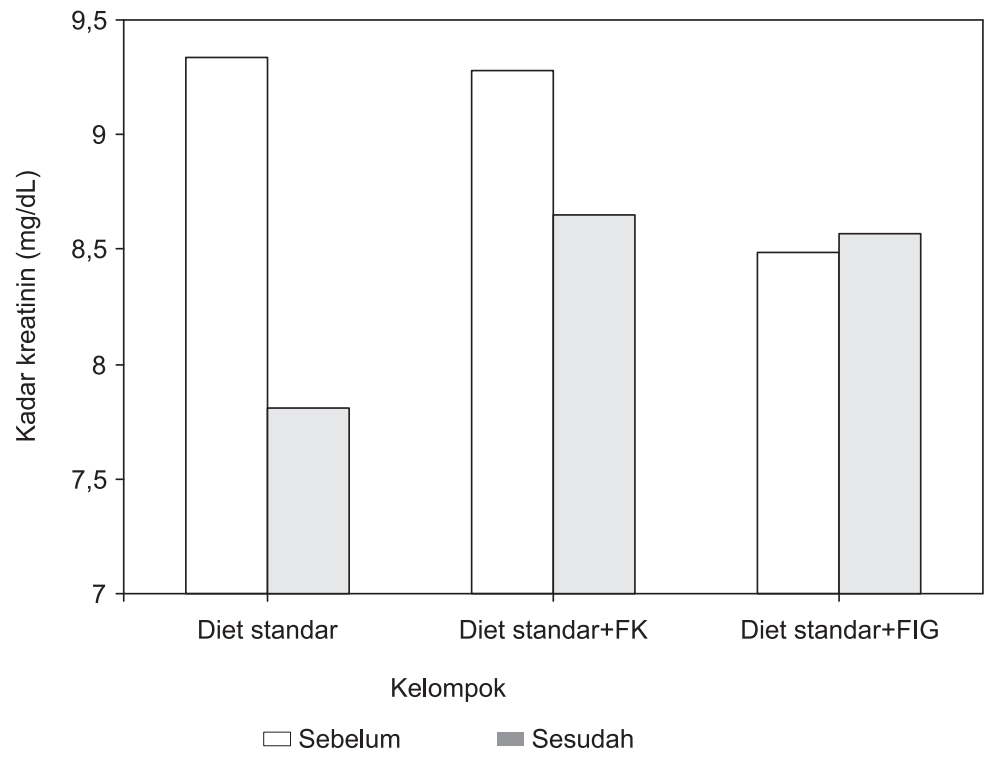

GAMBAR 2. Rerata kadar serum kreatinin subjek sebelum dan sesudah pemberian diet 
TABEL 7. Perubahan kadar serum kreatinin subjek sebelum dan sesudah pemberian diet

\begin{tabular}{|c|c|c|c|c|}
\hline \multirow[b]{2}{*}{ Kelompok } & \multicolumn{3}{|c|}{ Kadar serum kreatinin (mg/dL) } & \multirow[b]{2}{*}{$\mathbf{p}$} \\
\hline & $\begin{array}{c}\text { Sebelum } \\
(\text { mean } \pm S D)\end{array}$ & $\begin{array}{c}\text { Sesudah } \\
(m e a n \pm S D)\end{array}$ & $\begin{array}{c}\text { Selisih } \\
(m e a n \pm S D)\end{array}$ & \\
\hline Diet standar tanpa diet ekstra & $9,34 \pm 2,93$ & $7,81 \pm 4,35$ & $-1,54 \pm 3,21$ & 0,126 \\
\hline Diet standar + FK & $9,28 \pm 2,16$ & $8,65 \pm 3,31$ & $-0,63 \pm 2,99$ & 0,484 \\
\hline Diet standar + FIG & $8,49 \pm 3,17$ & $8,56 \pm 3,35$ & $0,08 \pm 1,39$ & 0,852 \\
\hline $\begin{array}{l}\text { Keterangan: } \\
\text { FK (formula komersial) } \\
\text { FIG (filtrat ikan gabus) } \\
p \quad \text { (uji t) }\end{array}$ & & & & \\
\hline
\end{tabular}

sehingga dapat dikatakan subjek homogen pada awal penelitian. Hasil penelitian yang dilakukan oleh Heacock (15) terhadap 142 penderita hemodialisis di Ohio, didapatkan adanya hubungan antara faktor demografi yaitu: status perkawinan, jenis kelamin, lama menjalani hemodialisis, dan pekerjaan dengan status gizi berdasarkan berat badan, LILA (lingkar lengan atas), lingkar otot lengan atas, tebal lemak trisep, albumin, transferin, total limfosit, dan parameter subjektif.

Jenis membran dialisis yang digunakan oleh seluruh subjek adalah membran polysulfone. Penggunaan jenis membran dialisis yang berbeda akan bepengaruh terhadap kehilangan asam amino. Peningkatan proses katabolisme lebih tinggi pada penderita hemodialisis yang menggunakan membran cuprophane dan terbukti dengan adanya kehilangan asam amino bebas dan peptida yang setara dengan pemecahan 15 gram protein ke dalam dialisat setelah darah terpapar dengan membran dialisis selama 150 menit (4).

Seluruh subjek pada awal penelitian menggunakan dialyzer yang baru dan sesudahnya pakai ulang (reused) sampai dengan lima kali pemakaian. Hal ini terutama karena pertimbangan ekonomi yaitu harga yang relatif mahal. Penggunaan membran dialisis pakai ulang akan memperburuk keadaan. Hal ini disebabkan adanya peningkatan pelepasan monokin (IL-1, TNF) dan endotoksin yang menginduksi katabolisme protein otot. Adapun jenis dialisat yang digunakan dalam penelitian ini adalah natrium bikarbonat. Penggunaan dialisat asetat berkaitan dengan kejadian mual, muntah, dan hipotensi (4).

Lama dialisis yang dijalani subjek kurang lebih 7-8 jam/ minggu. Hal ini memang kurang sesuai dengan yang dianjurkan yaitu antara 9-10 jam/minggu. Kondisi ini disebabkan kapasitas mesin dan ruangan yang disediakan tidak sesuai dengan jumlah penderita hemodialisis yang mencapai 254 penderita. Adekuasi dialisis merupakan faktor penting yang perlu diperhatikan. Hasil observasi pada pasien dengan PCR (polymerase chain reaction) rendah yang berarti asupan protein rendah dan dialisis tidak adekuat, tidak menunjukkan adanya peningkatan asupan protein meskipun dilakukan penyuluhan diet yang intensif dan pemberian suplementasi oral, sampai dosis dialisis yang diberikan adekuat (16).

Hasil penelitian menunjukkan rerata kadar serum albumin sebelum pemberian diet sebesar 3,62 $\pm 0,48 \mathrm{~g} / \mathrm{dL}$, dengan sebagian besar subjek tergolong mempunyai kadar serum albumin acceptable. Hal ini disebabkan 2 bulan sebelum penelitian dilakukan, sebagian besar penderita hemodialisis di Instalasi Dialisis RSU Dr. Saiful Anwar Malang mendapatkan tambahan plasbumin, karena kadar albumin 3 bulan sebelumnya sangat rendah. Sejalan dengan hasil penelitian ini, rerata kadar serum albumin penderita dengan hemodialisis rutin di RSUP Dr. Sardjito Yogyakarta sebesar 3,24 g/dL atau berkisar antara 2,27-4,26 g/dL (17). Berbeda dengan hasil penelitian ini, Veeneman et al. (18) membuktikan hasil yang lebih tinggi yaitu sebesar 3,9 0,2 g/dL. Demikian pula hasil penelitian Ray (19) yang menunjukkan rerata kadar serum albumin subjek sebesar $3,7 \mathrm{~g} / \mathrm{dL}$. Hal ini dimungkinkan karena perbedaan pola makan subjek yang relatif lebih tinggi protein dibandingkan kebiasaan makan di Indonesia. Perbedaan kadar serum albumin subjek dari ketiga kelompok pada awal penelitian secara statistik tidak signifikan, sehingga dapat dikatakan subjek homogen berdasarkan kadar serum albumin awal.

Kadar serum kreatinin subjek pada awal penelitian tidak menunjukkan perbedaan yang signifikan $(p>0,05)$. Rerata kadar serum kreatinin awal sebesar 9,04 $\pm 2,73 \mathrm{mg} / \mathrm{dL}$ dan sebagian besar subjek mempunyai status kreatinin kurang (tidak optimal). Hasil ini lebih rendah daripada nilai yang didapatkan dari penderita hemodialisis di RSUP Dr. Sardjito Yogyakarta sebesar 13,24 mg/dL (17). Kadar serum kreatinin dipengaruhi oleh status gizi. Produksi kreatinin merupakan fungsi dari massa otot. Subjek dengan penurunan massa otot akan mempunyai kreatinin yang lebih rendah dibandingkan subjek dengan status gizi yang baik. Status gizi subjek berdasarkan indeks massa tubuh juga tidak menunjukkan perbedaan yang signifikan, sehingga subjek penelitian dapat dikatakan homogen.

\section{Asupan energi dan protein subjek}

Hasil penelitian menunjukkan bahwa asupan energi subjek masih tergolong rendah, dengan rerata $74,34 \pm 4,71 \%$ dari kebutuhan atau sekitar 26,1 $\pm 1,6 \mathrm{kkal} / \mathrm{kg} \mathrm{BBI} /$ hari. Sejalan dengan penelitian ini, penderita malnutrisi di Cina memiliki rerata asupan energi sebesar $28,1 \pm 4,6 \mathrm{kkal} / \mathrm{kg} \mathrm{BB}$ (berat badan)/hari dan HEMO (hemodialysis) study di Amerika Serikat menunjukkan rerata asupan energi sebesar 22,8 \pm $8,8 \mathrm{kkal} / \mathrm{kg} \mathrm{BB} /$ hari (20). Hasil penelitian terhadap penderita hemodialisis di RSUP Dr. Sardjito Yogyakarta juga 
menunjukkan masih rendahnya asupan energi penderita yaitu sebesar 31,69 4 4,47 kkal/kg BB/hari (17).

Rendahnya asupan energi pada subjek penelitian disebabkan adanya keluhan gastrointestinal berupa mual yang dialami oleh subjek dan anoreksia yang terjadi pada sebagian besar subjek. Menurut Kalantar et al. (21), asupan energi yang rendah disebabkan adanya penurunan nafsu makan karena faktor psikososial, seperti: kesepian, depresi, sosial ekonomi, dan masalah gigi. Faktor penyebab lainnya adalah kardiovaskuler yang tidak stabil, adanya penyakit penyerta lain, kelelahan setelah terapi hemodialisis, rasa mual, dan muntah. Secara fisiologis, kehilangan nafsu makan dapat disebabkan obat-obatan yang diberikan, hemodialisis yang tidak adekuat, dan komponen cairan dialisatnya (22).

Pada penelitian ini, asupan energi pada kelompok dengan diet ekstra formula komersial mempunyai rerata lebih tinggi dibandingkan dua kelompok lainnya, namun perbedaan ini tidak signifikan $(p>0,05)$, sehingga dapat dikatakan subjek homogen berdasarkan asupan energi. Pemberian suplementasi oral dengan formula padat energi dan protein bagi penderita hemodialisis yang seringkali mengalami gangguan nafsu makan dan pembatasan cairan perlu dilakukan (23). Sharma et al. (24) juga mengungkapkan bahwa pemberian suplementasi nutrisi enteral dapat meningkatkan asupan energi subjek sampai dengan 500 kalori.

Hasil penelitian menunjukkan rerata asupan protein subjek sebesar $74,41 \pm 8,81 \%$ kebutuhan atau sekitar $0,89 \pm$ $0,11 \mathrm{~g} / \mathrm{kg} \mathrm{BBI} / \mathrm{hari}$. Rerata tersebut masih tergolong rendah. Sejalan dengan hasil penelitian ini, pada penderita hemodialisis di RSUP Dr. Sardjito Yogyakarta diperoleh rerata asupan protein sebesar $0,96 \mathrm{~g} / \mathrm{kg} \mathrm{BBI} / \mathrm{hari}(17)$. Hasil HEMO study di Amerika Serikat juga menunjukkan masih rendahnya rerata asupan protein subjek sebesar $0,94 \pm 0,36 \mathrm{~g} / \mathrm{kg} \mathrm{BBI} /$ hari (20). Salah satu penyebab rendahnya asupan protein adalah masih takutnya pasien untuk mengkonsumsi protein nabati karena anjuran diet sebelumnya, harga protein hewani yang relatif lebih mahal, dan pasien bosan mengkonsumsi protein hewani. Kurangnya konseling gizi yang intensif untuk memberikan informasi pada penderita tentang perubahan diet ini akan memperburuk kondisi ini.

Rerata asupan protein subjek dari diet sehari-hari menunjukkan perbedaan yang tidak signifikan $(p>0,05)$. Pemberian suplementasi oral, konseling gizi, serta terapi diet intradialisis terbukti dapat meningkatkan asupan protein subjek di samping dapat menggantikan glukosa dan protein yang hilang bersama cairan dialisat (25). Hasil penelitian Veeneman et al. (18) membuktikan bahwa daya terima penderita hemodialisis terhadap blended formula yang diperkaya dengan protein cukup baik dan dapat meningkatkan asupan protein. Demikian pula hasil penelitian Ray (19) yang menunjukkan bahwa suplementasi oral dengan pemberian protein susu dapat meningkatkan asupan protein dan kadar serum albumin penderita. Rekomendasi Mendez et al. (26) bahwa terapi diet intradialisis dengan formula tinggi protein (albumin) sangat diperlukan oleh pasien dengan hemodialisis yang sering mengalami hipoalbuminemia.

Hasil penelitian ini juga menunjukkan bahwa pemberian suplementasi oral dapat meningkatkan asupan makanan, meskipun tidak semua penelitian menunjukkan hasil yang sama. Penderita hemodialisis yang mengkonsumsi makanan oral intradialisis berlebihan juga akan menyebabkan terjadinya penurunan tekanan darah (9). Menurut Wilkens (27), nutrisi intradialisis dapat menggantikan asam amino yang hilang segera selama hemodialisis. Pemberian nutrisi oral pada penderita tanpa indikasi nutrisi parenteral akan lebih menguntungkan karena lebih dapat ditoleransikan oleh penderita dan mengandung zat gizi yang lebih lengkap termasuk vitamin dan mineral. Rendahnya asupan energi dan protein pada pasien dengan hemodialisis rutin berhubungan erat dengan risiko terjadinya kematian (28).

Hasil penelitian ini menunjukkan bahwa pemberian diet ekstra intradialisis dengan formula yang sesuai dengan kebutuhan dapat diterima oleh subjek dengan baik. Oleh karena itu, pemberian diet ekstra intradialisis porsi kecil padat energi dan protein perlu dipertimbangkan sebagai bagian terapi diet yang sangat dibutuhkan oleh pasien dengan hemodialisis yang pada umumnya mengalami gangguan nafsu makan.

\section{Pengaruh pemberian diet intradialisis terhadap kadar serum albumin}

National Kidney Foundation/Kidney Disease Outcome Quality Initiative atau NKF/KDOQI (29) merekomendasikan bahwa serum albumin merupakan indikator yang baik digunakan untuk menilai status gizi penderita dengan hemodialisis. Hasil penelitian ini menunjukkan adanya perbedaan rerata kadar serum albumin sebelum dan sesudah pemberian diet yang signifikan $(p=0,000)$. Secara umum, terjadi penurunan rerata kadar serum albumin subjek sebesar $0,23 \pm 0,39 \mathrm{~g} / \mathrm{dL}$. Hasil ini sejalan dengan penelitian Bellizzi et al. (30) yang memperoleh penurunan kadar serum albumin sebesar 0,30 $\pm 0,01 \mathrm{~g} / \mathrm{dL}$ sebelum dan sesudah penelitian. Hal ini disebabkan masih rendahnya asupan energi dan protein subjek, asidosis metabolik yang memberikan kontribusi terjadinya proteolisis otot, dan menurunkan sintesis protein (31). Pada akhir penelitian didapatkan hasil rerata kadar serum albumin kelompok tanpa diet ekstra lebih rendah daripada kelompok yang mendapatkan diet ekstra $(p=0,000)$. Hasil uji DMRT menunjukkan tidak ada perbedaan rerata kadar serum albumin antara kelompok yang mendapatkan diet ekstra formula komersial dan filtrat ikan gabus. Hal ini menunjukkan bahwa pemberian diet ekstra intradialisis dapat mempertahankan dan meningkatkan kadar serum albumin, sebagai akibat adanya asupan protein selama proses hemodialisis sehingga dapat menggantikan asam amino yang hilang terutama pada saat hemodialisis.

Hasil penelitian Ray (19) menunjukkan bahwa terjadi peningkatan rerata kadar serum albumin dari $3,38 \mathrm{~g} / \mathrm{dL}$ menjadi 
3,7 $\mathrm{g} / \mathrm{dL}$, setelah pemberian suplementasi protein peroral dengan $0,48 \mathrm{~g}$ procel protein/hari. Pemberian makanan tambahan secara oral intradialisis juga terbukti dapat meningkatkan berat badan, arm muscle circumference, albumin, dan transthyretin (prealbumin) (31).

Berdasarkan uji statistik ( $t$-test), rerata penurunan kadar serum albumin pada kelompok tanpa diet ekstra cukup signifikan $(p=000)$, di samping itu juga terjadi penurunan status albumin yang signifikan pada kelompok ini $(p=0,000)$. Pada kelompok dengan diet ekstra formula komersial, terjadi rerata penurunan kadar serum albumin yang signifikan, meskipun nilainya lebih rendah daripada kelompok tanpa diet ekstra. Kadar albumin yang rendah dipengaruhi oleh berbagai faktor seperti: inflamasi, asupan protein yang rendah, zat gizi yang hilang selama dialisis, asidosis metabolik, dan gangguan hormonal karena uremia $(1,32,33)$. Penurunan rerata kadar albumin subjek pada kelompok yang mendapatkan diet ekstra formula komersial tidak mempengaruhi status albumin subjek. Hasil uji statistik menunjukkan tidak terdapat perbedaan yang signifikan antara status albumin sebelum dan sesudah pemberian formula komersial pada kelompok ini $(p=0,174)$. Di samping itu, hasil uji statistik juga menunjukkan tidak terdapat perbedaan rerata kadar serum albumin yang signifikan antara kelompok yang mendapatkan formula komersial dan filtrat ikan gabus. Hal ini membuktikan bahwa pemberian diet ekstra intradialisis dapat mempertahankan kadar serum albumin agar tidak terjadi penurunan yang lebih tinggi. Pada kelompok yang mendapatkan diet ekstra filtrat ikan gabus terjadi kenaikan rerata kadar serum albumin sebesar 0,06 g/ $\mathrm{dL}$ dan terjadi kenaikan status albumin subjek yang signifikan $(p=0,021)$. Ikan gabus memiliki kelebihan kandungan albumin yang cukup tinggi dibandingkan dengan sumber protein hewani yang lain (34). Oleh karena itu, meskipun perbedaan asupan energi dan protein ketiga kelompok tidak signifikan, pemberian diet intradialisis terbukti dapat mempertahankan kadar serum albumin subjek karena menggantikan protein yang hilang selama proses hemodialisis dan diet ekstra yang diberikan keduanya berasal dari sumber protein hewani susu dan ikan yang mempunyai nilai biologis tinggi.

Hemodialisis merupakan proses katabolik dan selama proses hemodialisis ini otot akan melepaskan asam-asam amino (35). Untuk mempertahankan keseimbangan nitrogen dibutuhkan protein sebanyak 1,2 g/kg BBI/hari dengan proporsi minimal $50 \%$ protein bernilai biologis tinggi dan berasal dari protein hewani. Protein bernilai biologis tinggi karena memiliki komposisi asam amino yang sesuai dengan protein tubuh $(27,29)$. Diet tinggi protein dapat menimbulkan keseimbangan nitrogen positif atau netral, tetapi kadangkadang diet tinggi protein dengan nilai biologis rendah menimbulkan keseimbangan nitrogen negatif (4).

Terjadinya penurunan kadar serum albumin maupun rendahnya kenaikan kadar serum albumin pada kelompok yang mendapatkan diet ekstra kemungkinan disebabkan kurangnya dosis protein yang diberikan dan waktu pemberian yang relatif singkat, meskipun waktu paruh albumin telah terpenuhi $(18,36)$. Hasil penelitian Ray (19) menunjukkan terjadinya peningkatan rerata kadar serum albumin setelah pemberian suplementasi protein peroral selama 6 bulan, sedangkan hasil penelitian Tietze dan Pedersen (37) menunjukkan terjadinya perubahan profil asam amino dan peningkatan berat badan setelah mendapatkan suplementasi minyak ikan secara oral selama 3 bulan. Dari hasil penelitian ini, dapat disimpulkan bahwa pemberian terapi diet ekstra intradialisis baik formula komersial maupun filtrat ikan gabus dapat mempertahankan kadar serum albumin dan status albumin pasien dengan hemodialisis.

\section{Pengaruh pemberian diet intradialisis terhadap kadar serum kreatinin}

Kadar serum kreatinin yang rendah ( $<10 \mathrm{mg} / \mathrm{dL}$ ) pada pasien hemodialisis menggambarkan malnutrisi energi protein serta wasting (29) dengan nilai rerata normal sebesar 12-15 $\mathrm{mg} / \mathrm{dL}$ (38). Tingginya kadar serum kreatinin berhubungan dengan rendahnya risiko mortalitas dan juga tingginya dosis hemodialisis (39). Hasil penelitian menunjukkan terdapat penurunan rerata kadar serum kreatinin pada awal dan akhir penelitian, namun secara statistik perbedaan kadar serum kreatinin awal dan akhir penelitian ini tidak signifikan $(p>0,05)$.

Demikian pula rerata kadar serum kreatinin subjek pada akhir penelitian yang juga menunjukkan hasil tidak signifikan ( $p>0,05)$. NKF/KDOQI (29) merekomendasikan agar intrepretasi serum kreatinin sebagai parameter status gizi juga mempertimbangkan ekskresi kreatinin urin. Hal ini kemungkinan yang belum dilakukan dalam penelitian ini, di samping singkatnya waktu pengamatan untuk penilaian kadar serum kreatinin. Rendahnya asupan energi dan protein subjek, meskipun telah mendapatkan diet ekstra, merupakan salah satu faktor kurangnya peningkatan kadar serum kreatinin pada akhir penelitian. Di samping itu, kurangnya waktu hemodialisis dari yang dianjurkan juga berperanan terhadap rendahnya perubahan kadar serum kreatinin pada akhir penelitian. Sejalan dengan penelitian ini, Dwyer et al. (20) membuktikan bahwa kadar serum kreatinin $>11 \mathrm{mg} / \mathrm{dL}$ berhubungan dengan hemodialisis yang adekuat, konsentrasi protein somatik, massa otot, serta status gizi.

Pemberian diet intradialisis dapat meningkatkan asupan energi dan protein, namun tidak akan berefek baik pada status gizi jika asupan sehari-hari masih rendah $(18,28,40)$. Asupan energi yang adekuat sangat diperlukan untuk mencegah katabolisme jaringan tubuh. Asupan energi yang optimal dari golongan bahan makanan nonprotein ini dimaksudkan untuk mencegah penggunaan protein sebagai sumber energi (4). Pada dasarnya pemberian diet intradialisis tinggi protein bertujuan untuk menggantikan protein yang hilang selama hemodialisis. Oleh karena itu, diberikan sumber protein hewani yang bernilai biologis tinggi untuk mempertahankan keseimbangan nitrogen positif, 
meningkatkan kadar albumin dan kreatinin pasien dengan hemodialisis. Namun demikian, kondisi ini tidak akan tercapai maksimal jika asupan energi dan protein pasien sehari-hari masih rendah.

\section{KESIMPULAN DAN SARAN}

Rerata kadar serum albumin subjek yang mendapatkan diet ekstra formula komersial lebih tinggi secara signifikan dibandingkan subjek yang tidak mendapatkan diet ekstra. Demikian pula dengan rerata kadar serum albumin subjek yang mendapatkan diet ekstra filtrat ikan gabus lebih tinggi secara signifikan dibandingkan subjek yang tidak mendapatkan diet ekstra. Tidak terdapat pengaruh yang signifikan pemberian diet ekstra terhadap pencapaian kadar serum kreatinin optimal pada subjek.

\section{RUJUKAN}

1. Perhimpunan Nefrologi Indonesia Pernefri. Konsensus Dialisis. Jakarta: Pernefri; 2003.

2. Hung YM, Lee SJ. Analysis of Early and Late Mortality of Chronic Hemodialysis Patients in A Hemodialysis Center of Southern Taiwan. Dial Transplant 2003;32(4):198-203.

3. Bakri S. 22 Tahun Menggeluti Penyakit Ginjal. Kompas 3 September 2005; Sect. A:1 (col.1-3).

4. Kopple J, Massry SG. Nutritional Management of Renal Disease. Philadelphia: Lippincott Williams \& Wilkins; 2003.

5. Pollock CA, Ibels LS, Allen BJ. Nutritional Markers and Survival in Maintenance Dialysis Patients. Nephron 1996;74;625-41.

6. Protica. Protein Requirements During Treatment of Renal Failure. Protica Publications; 6 Mei 2005.

7. Foulks CJ. The Effect of Intradialytic Parenteral Nutrition on Hospitalization Rate and Mortality in Malnourished Hemodialysis Patiens. J Ren Nutr 1996;4:5-10.

8. Ruggian JC, Fishbane S, Frei GL. Effect of Intradialytic Parenteral Nutrition (IDPN) on Hypoalbunemic Hemodialysis (HD) Patients. J Am Soc Nephrol 1994;5:502.

9. FitzGerald RJ, Murray BA, Walsh DJ. Hypotensive Peptides from Milk Proteins. J Nutr 2004;134:980S-8S.

10. Soemarko. Pengaruh Diet Ikan Kutuk dan Putih Telor terhadap Peningkatan Albumin dan Penutupan Luka Operasi. Malang: RSSA; 1998.

11. Santosa A. Profil Zat Gizi Filtrat Ikan Gabus. Laporan Penelitian. Malang: Poltekkes Depkes Malang; 2005.

12. Suprayitno E, Moedjiharto TJ, Madkhoiri. Penggunaan Albumin Ikan Gabus (Ophiochephalus striatus) pada Penutupan Luka Tikus Putih Wistar. Malang: Universitas Brawijaya; 2003.
Hasil penelitian ini merekomendasikan agar pemberian diet intradialisis perlu dilakukan secara intensif untuk meningkatkan kadar serum albumin dan kreatinin pasien. Selain itu, perlu pula dilakukan kontrol terhadap faktor-faktor yang mempengaruhi kadar albumin dan kreatinin untuk penelitian lebih lanjut, antara lain: kadar kreatinin urin, BUN (blood urea nitrogen), dan derajat asidosis. Analisis lebih lanjut terhadap kandungan zat gizi filtrat ikan gabus dalam penatalaksanaan diet pasien dan peningkatan peran ahli gizi di instalasi dialisis dalam rangka konseling dan monitoring gizi pasien hemodialisis juga perlu dilakukan karena masih rendahnya asupan energi dan protein pasien.

\section{Ucapan terima kasih}

Terima kasih kepada seluruh pasien hemodialisis, para tenaga medis, dan paramedis di Instalasi Dialisis RSU Dr. Saiful Anwar Malang atas partisipasi dan kerjasamanya.

13. Lemeshow S, Hosmer D, Klar J. 1990. Adequacy of Sample Size in Health Studies. (Terjemahan) Pramono D. Yogyakarta: UGM Press; 1997. h. 49-52.

14. Sastroasmoro S, Ismael S. Dasar-Dasar Metodologi Penelitian Klinis. Jakarta: Binarupa Aksara; 1995.

15. Heacock P, Nabel J, Norton P, Heile S, Royse D. An Exploration of The Relationship Between Nutritional Status and Quality of Live in Chronic Hemodialysis Patients. J Ren Nutr 1996;6(3):152-7.

16. Lindsay R, Spanner E, Heidenheim P, Le Febure JM. (1992) Wich Comes First. Kt/V or PCR Chicken or Egg? Kidney Int;42:S32-7.

17. Susetyowati. Peranan Konsultasi Gizi Berkelanjutan terhadap Kadar Albumin Serum Penderita Penyakit Ginjal Kronik dengan Hemodialisis di RS Dr Sardjito Yogyakarta. Berkala Kesehatan Klinik 2005;XI(1):22-5.

18. Veeneman JM, Kingma HA, Boer TS. Protein Intake During Hemodialysis Maintains A Positive Whole Body Protein Balance in Chronic Hemodialysis Patients. Am J Physiol 2003;284:E954-65.

19. Ray C. Protein Supplementations in Patients Using Peritoneal Dyalisis. J Ren Nutr 2005;15(2):260-4.

20. Dwyer JT, Larive B, Leung J. Nutritional Status Affects Quality of Life in Hemodialysis (HEMO) Study Patients at Baseline. J Ren Nutr 2002;22:213-33.

21. Kalantar ZK, Kopple DJ, Deepak S. Food Intake Characteristics of Hemodialysis Patients As Obtained by Food Frequency Questionnaire. J Ren Nutr 2002;12:1721.

22. Akner G, Cederholm. Treatment of Protein Energy Malnutrition in Chronic Nonmalignant Disorder. Am J Clin Nutr 2001;74(1):6-7.

23. Cano N. Hemodialysis, Inflammation and Malnutrition. Nefrol 2001;XXI:1-9. 
24. Sharma M, Rao M, Jacob S, Jacob CK. A Controlled Trial of Intermittent Enteral Nutrition Supplementation in Maintenance Hemodialysis Patients. J Ren Nutr 2002;12:29-37.

25. Sidabutar RP, Suhardjono, Kapojos EJ. Gagal Ginjal Kronik. Dalam: Soeparman, Waspadji S, editors. IImu Penyakit Dalam. Jakarta: Balai Penerbit FKUI; 1991.

26. Mendez CM, McClain CJ, Marsono LS. Albumin Therapy in Clinical Practise. Nutr Clin Pract 2005;20(3):314-20.

27. Wilkens KG. Medical Nutrition Therapy for Renal Disorders. In: Mahan LK, Stump SE, editors. Krause's: Food Nutrition and Diet Therapy. $11^{\text {th }}$ edition. Philadelphia: WB Saunders; 2004. pp. 970-85.

28. De Arau'jo IC, Kamimura MA, Draibe SA, Canziani M, Manfredi SR, Avesani, et al. Nutritional Parameters and Mortality in Incident Hemodialysis Patients. J Ren Nutr 2006;16(1):27-35.

29. National Kidney Foundation/Kidney Disease Outcome Quality Initiative (NKF/KDOQI). Clinical Practical Guidelines for Chronic Kidney Disease: Evaluation, Classification, and Stratification. Am J Kidney Dis 2002;39(2):S1-S246.

30. Bellizzi V, lorio BR, Terracciano V, Minutolo R, lodice C, Nicola LD, et al. Daily Nutrition Intake Represents AModifiable Determinant of Nutritional Status in Chronic Hemodialysis Patients. Nephrol Dial Transplant 2003;18:1874-81.

31. Cano N. Malnutrition and Hemodialysis. Paper Presented at The Meeting of ESPEN Congress Canes. 2003.
32. Jones $\mathrm{CH}$. Serum Albumin in Peritoneal Dialysis Patients. Paper Presentet at The Meeting of $3^{\text {th }}$ Congress of Nephrology in Internet: 2003; New York, USA.

33. Rigby JA. Growing Numbers of People with Chronic Kidney Disease Require that Dietitians Get Up to Speed on Prevention and Treatment. Kidney Dis 2004;6(11):44.

34. DeMan JM. Kimia Makanan. (Terjemahan) Ismadi M. Edisi Kedua. Jakarta: EGC;.1997.

35. Lim VS, Ikizler TA. Does Hemodialysis Increase Protein Breakdown? Dissociation Between Whole Body Amino Acid Turnover and Regional Muscle Kinetics. J Am Soc Nephrol 2005;16:862-8.

36. Pupim LB, Flakoll PJ, Ikizler TA. Nutritional Supplementation Acutely Increases Albumin Fractional Synthetic Rate in Chronic Hemodialysis Patients . J Am Soc Nephrol 2004;15:1920-6.

37. Tietze IN, Pedersen EB. Effect of Fish Protein Supplementation on Amino Acid Profile and Nutritional Status in Hemodialysis Patients. Nephrol Dial Transplant 1991;6:948-54

38. Mitch WE, Goldberg AL. Mechanisms of Muscle Wasting. N Engl J Med 2004;25(335):1897-905.

39. Iseki K, Kawazoe N, Fukiyama K. Serum Albumin is A Strong Predictor of Death in Chronic Dialysis Patients. Kidney Int 1999;44:115-9.

40. Williams. Early Clinical, Quality of Life and Biochemical Changes of Daily Hemodialysis. Am J Kidney Dis 2004;43(1):169-70. 